\title{
ON THE HETEROTREME-THORACOTREMEDISTINCTION IN THE EUBRACHYURA DE SAINT LAURENT, 1980 (DECAPODA, BRACHYURA)
}

\author{
BY
}

\author{
RICHARD VON STERNBERG ${ }^{1}$ ) and NEIL CUMBERLIDGE ${ }^{2}$ ) \\ 1) Department of Invertebrate Zoology, NHB-163, Smithsonian Institution, Washington, \\ D.C. 20560, U.S.A. \\ 2 ) Department of Biology, Northern Michigan University, Marquette, MI 49855, U.S.A.
}

\begin{abstract}
Eubrachyurans are currently divided into two subsections based on the anatomical position of the seminal duct termini. Heterotremes have the seminal ducts passing through the pereiopod 5 coxae, emerging externally in the form of "penes" to contact the basal segments of the gonopods. Thoracotrematous crabs, on the other hand, have the "male openings" located on sternite 8 and the ejaculatory ducts never pass through the pereiopod 5 coxae. Some brachyurologists maintain in the literature that the heterotreme-thoracotreme distinction reflects the extremes of two evolutionary grades. According to this speculation, "advanced" thoracotrematous crabs probably arose from intermediate goneplacid forms which, in turn, originated out of the Heterotremata in response to selection pressures for improved locomotion. The cladistic hypothesis of De Saint Laurent (1980), in contrast, positions Heterotremata and Thoracotremata as sister groups. Indeed, the heterotremethoracotreme difference considered alone does support two discrete types as no truly intermediate seminal duct condition bridges the subsections. Nor is there any evidence to suggest that the heterotrematous state is the anatomical precursor of sternal openings for the seminal ducts. The fact that basal members of the Pinnotheroidea De Haan are thoracotremes whereas more derived forms have an heterotrematous morphology, refutes De Saint Laurent's hypothesis of a deep phylogenetic cleavage between the two subsections. In addition to this information, the $850_{+}$species of freshwater crabs (many of which are semi-terrestrial) share an array of somatic apomorphies with thoracotremes and yet belong to the Heterotremata. And the cladistic hypothesis of De Saint Laurent (1980) is also falsified by previous parsimony analyses which place a monophyletic taxon Thoracotremata within a paraphyletic group Heterotremata. It is therefore possible that Heterotremata is synonomous with Eubrachyura, with Thoracotremata remaining as a distinct eubrachyuran subclade. One trenchant conclusion is that the functional explanation for the heterotreme-thoracotreme distinction lacks empirical support.
\end{abstract}

\section{RÉSUMÉ}

Les Eubrachyura sont couramment divisés en deux sous-sections, sur la base de la position anatomique de l'extrémité des canaux séminaux. Les hétérotrèmes ont un canal séminal qui traverse la coxa du péréiopode 5, débouchant à l'extérieur sous la forme d'un pénis au contact de l'article basal du gonopode. Les crabes thoracotrèmes, d'autre part, ont les orifices sexuels mâles situés sur le 
sternite 8, et le canal éjaculateurne passe jamais par la coxa du péréiopode 5. Certains carcinologistes maintiennent que la distinction hétérotrème-thoracotrème reflète les extrêmes de deux grades d'évolution. Selon cette opinion, les crabes thoracotrèmes "avancés" seraient probablement issus de formes gonéplaciennes intermédiaires qui auraient leur origine dans les Heterotremata en réponse aux pressions de sélection pour améliorer la locomotion dans des environnements semiterrestres. L'hypothèse cladistique proposée par De Saint-Laurent (1980), en revanche, considère les Heterotremata et les Thoracotremata comme groupes-frères. En effet, la différence hétérotrèmethoracotrème considérée seule supporte deux formes discrètes, étant donné qu'aucune condition intermédiaire du canal séminal ne relie les deux sous-sections. De même, aucune évidence ne suggère que l'état hétérotrème est le précurseur anatomique de l'ouverture sternale du canal séminal. Le fait que les membres basaux des Pinnotheroidea De Haan sont thoracotrèmes, alors que des formes plus dérivées ont une morphologie hétérotrème, réfute l'hypothèse de De SaintLaurent d'un clivage phylogénétique profond entre les deux sous-sections. En outre, les plus de 850 espèces de crabes d'eau douce (dont beaucoup sont semi-terrestres) partagent un ensemble d'apomorphies somatiques avec les thoracotrèmes et, cependant, appartiennent aux Heterotremata. De plus, l'hypothèse cladistique de De Saint-Laurent (1980) est également falsifiée par les analyses de parcimonie antérieures qui placent un taxon monophylétique Thoracotremata à l'intérieur d'un groupe paraphylétique Heterotremata. Il est alors possible que Heterotremata soit synonyme de Eubrachyura, les Thoracotremata restant un sous-clade eubrachyourien distinct. Une conclusion nette est que l'explication fonctionnelle pour la distinction hétérotrème-thoracotrème manque d'un support empirique.

\section{INTRODUCTION}

The classification of brachyuran crabs was substantially revised in a series of detailed works that focused primarily on the position of the female and male sexual openings, thoracic sternal patterns, aspects of the endophragmal system, male first and second pleopods, and male abdomen locking mechanisms (Guinot, 1978, 1979). Guinot's studies led to the proposal of a logical (if perhaps not phylogenetic) system of brachyuran relationships. Three new sections of the Brachyura were proposed (Podotremata, Heterotremata, and Thoracotremata) with partitions based in part on the anatomical location of the female and male sexual apertures (see Guinot, 1978, 1979). The section Podotremata contains all brachyuran families in which the orifices of the oviducts are located on the coxae of the third pereiopods, and where the spermathecal openings are located on the border of thoracic sternites 7 and 8, with the spermathecae separated from the ovaries and oviducts (Hartnoll, 1968). All podotremes have the male sexual apertures on the coxae of the fifth pereiopods. The sexual character states diagnostic for the Podotremata are considered generalized conditions for the Brachyura. The sections Heterotremata and Thoracotremata share a set of trenchant apomorphies, including oviducts that open into the spermathecal chambers, spermathecal chambers that are connected to sternal vulvae via "vaginae", and vulvae that are positioned on sternite 6. Heterotremes and thoracotremes differ in that heterotremes have male 
sexual apertures ("penes") on the coxae of pereiopods 5, whereas thoracotremes have distinctly sternal male sexual apertures on thoracic sternite 8 .

Guinot $(1978,1979)$ suppressed the former divisions of the apodotreme Brachyura (such as the Brachyrhyncha and Oxyrhyncha of Borradaile, 1907) reassigning taxa to either the Heterotremata or the Thoracotremata (table I). At the same time, the Cyclometopa and Catometopa of H. Milne Edwards (1834-1837), groups that were partly defined by the relative positions of the male and female sexual openings, became largely synonymous with the Heterotremata and Thoracotremata, respectively.

Despite the inherent rationality of Guinot's $(1978,1979)$ brachyuran classification, there has been some debate as to whether Guinot's sections represent grades or lineages. De Saint Laurent (1980a, b) established the section Eubrachyura to include the subsections Heterotremata and Thoracotrema as two independent clades, and considered the Podotremata to be the sister taxon of the Eubrachyura (fig. 1A). The scheme of De Saint Laurent (1980a, b) is thus a cladistic one that emphasizes the anatomical gap separating podotremes and eubrachyurans at one level, and heterotremes and thoracotremes at another level. In a sense De Saint Laurent's hypothesis of relationships within the Brachyura can be seen as a reaction to speculations that the sexual states characteristic of the podotremes, heterotremes, and thoracotremes are merely gradistic responses to adaptational challenges. While it is now widely accepted that podotremes are morphologically distinct from eubrachyurans, the question of the monophyly of the two eubrachyuran subsections remains largely unresolved. The purpose of this paper is to assess the reality of the two subsections.

\section{RELATIONSHIPS OF THE PODOTREME TAXA WITH THE EUBRACHYURA}

Although aside from the main point of this paper, it should be noted that considerable debate surrounds the status of the Podotremata as a natural group (Guinot \& Bouchard, 1998). Trees of relationship based on comparisons of the 18S rRNA gene (Spears et al., 1992) present the podotremes and Brachyura as paraphyletic groups, with the dromiids aligned to the anomuran clade. Cladistic analyses using spermatozoal characters have in contrast supported the monophyly of both the Podotremata and Brachyura (Jamieson, 1994). No studies have refuted the monophyly of the Eubrachyura. Since the Podotremata is largely based on brachyuran symplesiomorphies, serious doubts exist as to whether this group (in toto) can be viewed as the sister taxon of the eubrachyurans. Thus, at least for the time being, it seems reasonable to recognize the podotrematous superfamilies Cyclodorippoidea Ortmann, 1892; Dakoticancroidea Rathbun, 1917; Dromiacea De Haan, 1833; Homoloidea De Haan, 1839; and Raninoidea De Haan, 1839, as forming an unresolved polytomy basal to the eubrachyurans (fig. 1B). 


\section{TABLE I}

List of families included in the eubrachyuran subsections Heterotremata and Thoracotremata (after Guinot \& Bouchard, 1998). Superfamilies are used instead of families when a "family" actually encompasses two or more family-level groupings

Heterotremata Guinot, 1977

Corystidae Samouelle, 1819

Atelecyclidae Ortmann, 1893

Cheiragonidae Ortmann, 1893

Thiidae Dana, 1852

Cancridae Latreille, 1803

Belliidae Dana, 1852

Orithyiidae Dana, 1852

Dorippidae MacLeay, 1838

Retroplumidae Gill, 1894

Palicidae Rathbun, 1898

Leucosiidae Samouelle, 1819

Calappidae De Haan, 1833

Matutidae MacLeay, 1838

Aethridae Dana, 1852

Hepatidae Stimpson, 1871

Parthenopidae MacLeay, 1838

Daldorfiidae Ng \& Rodríguez, 1986

Dairidae Ng \& Rodríguez, 1986

Inachoididae Dana, 1851

Macrocheiridae Dana, 1851

Majidae Samouelle, 1819

Oregoniidae Garth, 1958

Hymenosomatidae MacLeay, 1838

Portunoidea Rafinesque, 1815

Geryonidae Colosi, 1923

Eriphiidae Ortmann, 1893

Carpiliidae Ortmann, 1893

Platyxanthidae Guinot, 1977

Panopeidae Ortmann, 1893

Pilumnidae Samouelle

Trapeziidae Miers, 1886

Eumedonidae Miers, 1879

Xanthidae MacLeay, 1838

Bythograeidae Williams, 1980

Goneplacidae MacLeay, 1838 sensu lato

Potamoidea Ortmann, 1896 (including the Gecarcinucoidea Rathbun, 1904)

Pseudothelphusidae Ortmann, 1893

Trichodactylidae H. Milne Edwards, 1853

Cryptochiridae Paulson, 1875

THORACOTREMATA Guinot, 1977

Grapsidae MacLeay, 1838

Plagusiidae Dana, 1851

Sesarmidae Dana, 1851

Varunidae H. Milne Edwards, 1853 
TABLE I

(Continued)

Gecarcinidae MacLeay, 1838

Ocypodoidea Rafinesque, 1815

Camptandriidae Stimpson, 1858

Mictyridae Dana, 1851

Hexapodidae Miers, 1886

Pinnotheroidea De Haan, 1833

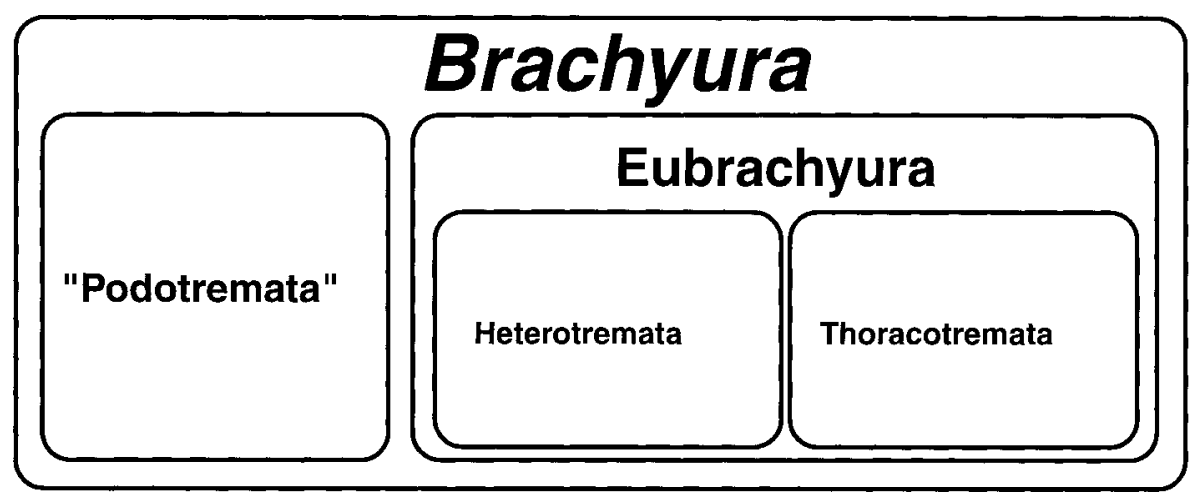

A

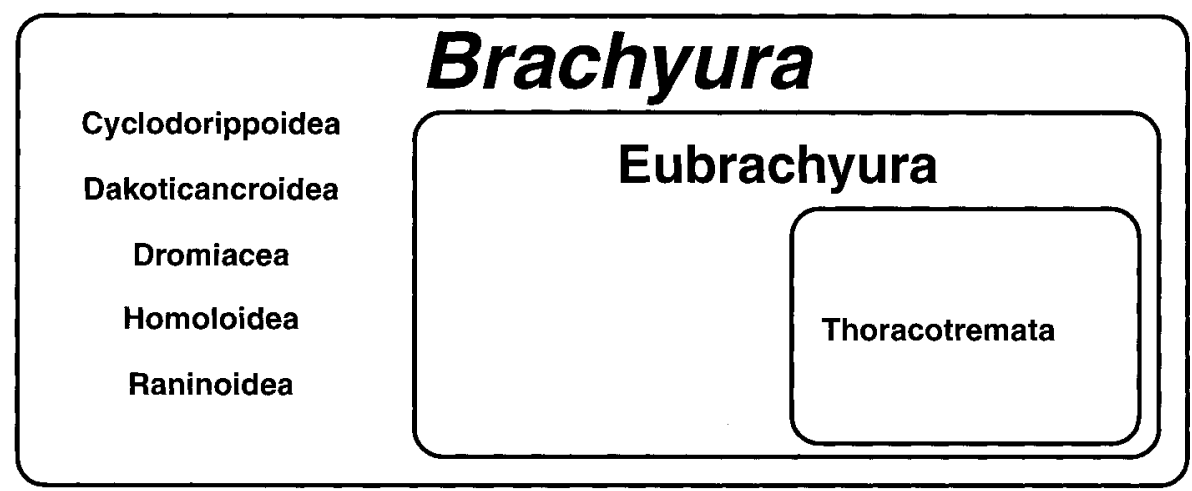

B

Fig. 1. Venn diagram representations of hierarchical relationships in the Brachyura: A, as proposed by De Saint Laurent (1980a, b); B, as proposed herein. Note that in B, the five podotrematous superfamilies (Guinot \& Bouchard, 1998) are presented as an unresolved assemblage relative to a monophyletic Eubrachyura. The double quotes surrounding the Podotremata in A indicate that this section was established using plesiomorphies (see Guinot, 1978, 1979). 

SPECULATION

Recent investigations (Von Sternberg \& Cumberlidge, 1999; Von Sternberg et al., 1999) into the position of the freshwater crab superfamilies Gecarcinucoidea Rathbun, 1904; Potamoidea Ortmann, 1896; and Pseudothelphusoidea Ortmann, 1893 within the Eubrachyura have again raised the issue of the monophyly of heterotremes and thoracotremes. However, a casual survey of the literature surrounding heterotreme or thoracotreme monophyly reveals that a priori transformational scenarios are often intermingled with discussions of anatomical states. One common assumption sometimes presented (e.g., Türkay, 1983; Hendrickx, 1998) is that heterotremes and thoracotremes represent the poles of a continuum, with a series of transitional forms in between. Adherents to this view hold (at least implicitly) that the two eubrachyuran subsections are grades resulting from changes to the fifth pereiopods and associated modifications of the thoracic sternum, brought about by selection pressures for improved locomotion (Magalhães \& Türkay, 1996).

Aside from the theoretical problems linked to adaptational thinking (Gould \& Lewontin, 1979), the above functional evolutionary interpretations tend to obscure considerations of the morphological conditions alone. That is, identification of anatomically homologous states becomes secondary to ideas of "adaptive zones". Another seemingly widespread belief, often conflated with the gradistic hypothesis, is that there is a distinct evolutionary trend leading from heterotremes to thoracotremes. The basis for deriving thoracotremes from heterotremes appears to reside in the still persistent (but often oversimplified) distinction between "primitive" cyclometopans versus "advanced" catometopans. The only way such an evolutionary trend can be validated is to demonstrate that the heterotrematous state is the ontogenetic or anatomical precursor of the thoracotreme morphology. (Note that cladistic analysis can support an hypothesis that one state is derived relative to another, but that this does not constitute evidence for an anagenetic trend.) To our knowledge there is no independent support (be it ontogenetic, anatomical, molecular, or theoretical) for an evolutionary trend leading from heterotremes to thoracotremes. The purpose of the present work is to evaluate the evidence pertinent to the resolution of these issues.

THE ANATOMICAL BASIS OF THE HETEROTREME-THORACOTREME DISTINCTION

A structuralist-morphological stance has been adopted here (Rieppel, 1990) whereby all a priori phylogenetic frameworks have been avoided. Instead, emphasis has been placed strictly on the relevant morphological states and their taxonomic distribution. This approach was followed in order to surpass the conceptual confusion that plagues the heterotreme-thoracotreme issue. 


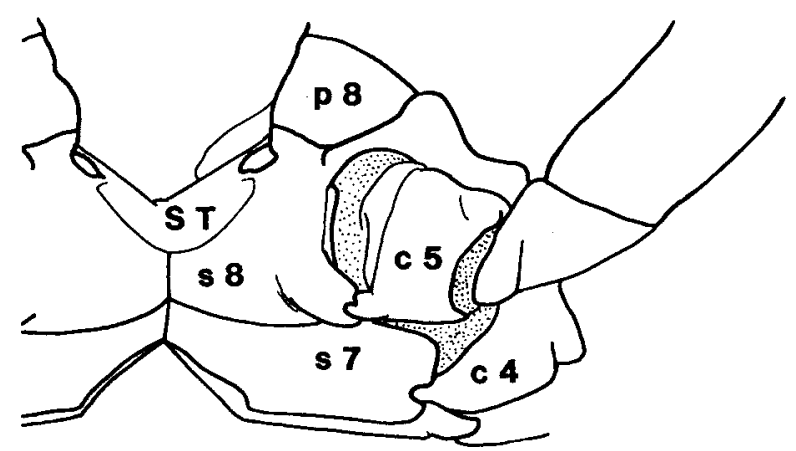

Fig. 2. Semidiagrammatic representation of the rearmost region of the eubrachyuran endophragmal system, showing the relations between the sella turcica (ST), sternite 8 (s8), the roof of endopleurite 8 (p8), and coxa 5 (c5). The posterior-view drawing is based on the endophragmal system of a male Eurytium sp. (Panopeidae).

An adult male Menippe frontalis A. Milne-Edwards, 1879, [University of Miami Marine Invertebrate Museum, uncatalogued, carapace length $(\mathrm{cl})=73 \mathrm{~mm}$, carapace width $(\mathrm{cw})=98 \mathrm{~mm}$ ] was dissected to provide details of the internal aspects of the heterotrematous condition (see fig. 2 for orientation of drawings). In Menippe the paired vasa deferentia diverge posteriorly, just anterior to the front of the sella turcica (see fig. 3A). The distal tracts of the vasa deferentia pass through the paired endophragmal openings formed by the lateral margins of the sella turcica, and the floor of endopleurite 8 (the latter is part of the "junction plate", Secretan, 1998). Each seminal duct then extends through the musculature of endosternite 8 (see Cochran, 1935) passing postero-laterally and ventrally to the aperture on the coxopodite of pereiopod 5 (the aperture being adjacent to the articulating membrane between the sternal margin and the coxopodite). The distal tract of each seminal duct is associated with the muscles of pereiopod 5, and together these structures pass through the endosternite 8 chamber to reach (at least partially) the coxopodite. It was determined that in Menippe the male sexual apertures on the coxa of pereiopod 5 are positioned posteriorly and ventrally to the junction between the lateral margin of the sella turcica and pleurite 8 (fig. 3A). The same holds for other dissected heterotrematous groups such as eriphiids, panopeids, and "goneplacids" (R. von Sternberg, unpublished material).

An adult male Ucides cordatus (Linnaus, 1763) [University of Miami Marine Invertebrate Museum, UMML 32: 3559, carapace length $(\mathrm{cl})=83 \mathrm{~mm}$, carapace width $(\mathrm{cw})=131.2 \mathrm{~mm}$ ] was dissected to provide details of the internal aspects of the thoracotrematous condition (fig. 3B). The topological relations of the sella turcica, vasa deferentia, endosternite 8 , and the apertures for the seminal ducts, when compared with Menippe, were found to be only slightly different in the thoracotreme Ucides. The only distinction is that in Ucides the coxa of pereiopod 5 is 


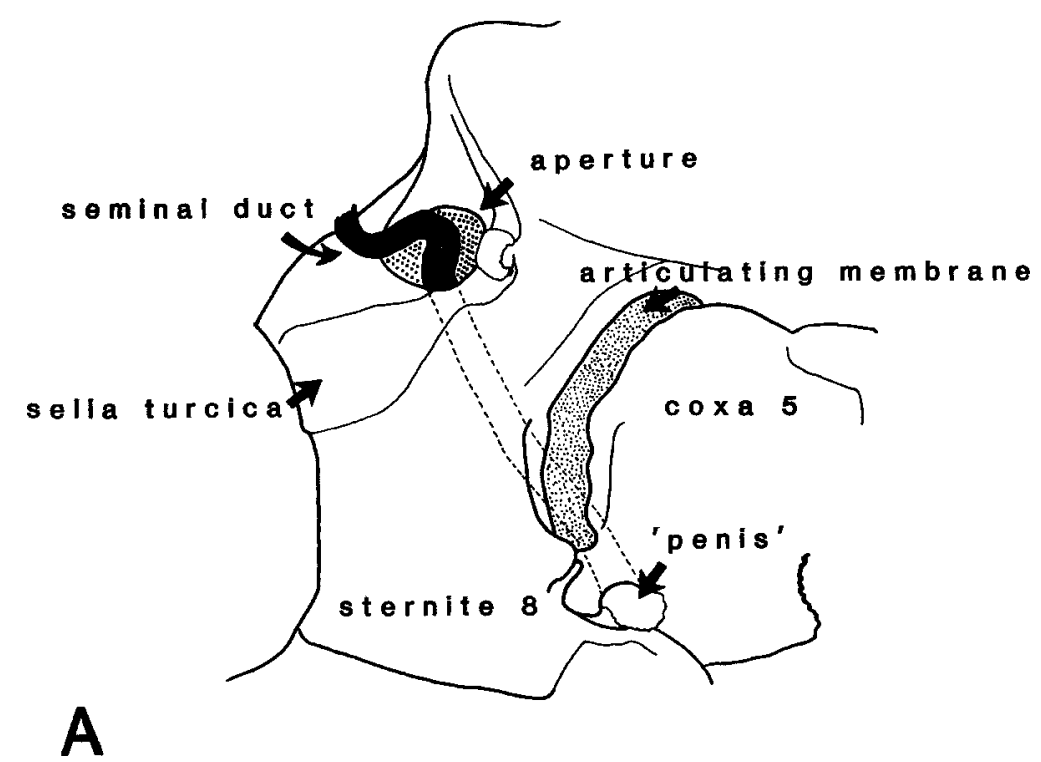

Fig. 3. Semidiagrammatic representation of the passage of the seminal ducts (vasa deferentia) around the sella turcica and through endosternite 8 (and coxa 5). A, the right and rear-most region of the Menippe frontalis A. Milne-Edwards, 1879 endophragmal system, sternite 8, and coxa 5 in posterior view. Note that the seminal duct passes through an aperture ("aperture") formed in part by the lateral margin of the sella turcica, moves through endosternite 8 , and then emerges via a coxal orifice. This is the typical heterotrematous condition. B, the right and rear-most section of the Ucides occidentalis (Ortmann, 1897) endophragmal system, sternite 8, and coxa 5 in posterior view. Note that the sternal orifice in Ucides takes the form of a raised opening on the anterior border of sternite 8 . The trajectory of the seminal duct in Ucides characterizes the thoracotrematous condition.

located more lateral to the trajectory of the seminal duct in endosternite 8 (fig. 3B). Nevertheless, the positioning of the vasa deferentia relative to the endophragmal system is nearly identical in Menippe and Ucides.

An important causal factor in the development of sternal apertures in Ucides and in other thoracotremes seems to be the widening of (endo)sternite 8 and the associated lateral displacement of the coxa of pereiopod 5. It should be noted though that some groups of heterotremes (e.g., many portunoids) also have widened eighth sternites which rules out using the expansion of this sternite as a determining factor. Whatever the generative rules involved in producing the heterotreme-thoracotreme distinction, the crucial discrepancy between the two groups hinges on the anatomical interplay between the vasa deferentia, the musculature of endosternite 8 , and the "floor" of endosternite 8 ("sternite 8"). Yet the apertures for the male sexual tubes must of necessity be either coxal or sternal because the seminal ducts never pass through the articulating membrane separating the coxa of the fifth pereiopod and the lateral margin of sternite 8 . This is presumably due to constraints arising from the need to maintain the integrity 


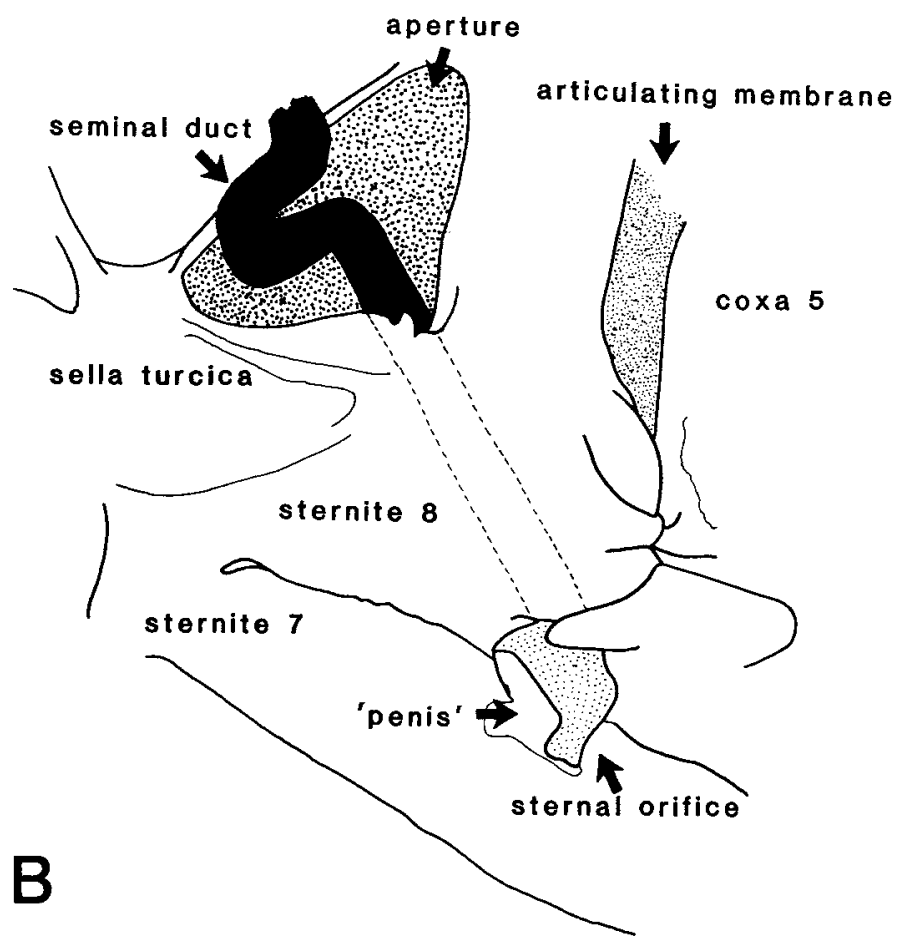

Fig. 3. (Continued).

of the seminal ducts/articulating membranes, and from interactions between the seminal ducts and the musculature of endosternite 8 . We therefore conclude here that the heterotreme-thoracotreme distinction is typological, and that the character upon which the partition is based does indeed establish two distinct groups within the Eubrachyura. Whether this typological distinction reflects a deep phylogenetic cleavage is another question.

\section{THE CASE OF SO-CALLED COXAL-STERNAL AND OTHER “INTERMEDIATE” MALE OPENINGS}

Many heterotrematous taxa possess what have been termed "coxal-sternal" apertures, and some authors have interpreted this condition as representing an intermediate anatomical state between the two main character states (coxal and sternal male sexual apertures). Examples of taxa with coxal-sternal apertures include the goneplacid subfamilies Carcinoplacinae H. Milne Edwards, 1852; Euryplacinae Stimpson, 1871; and Goneplacinae MacLeay, 1838; the panopeid Prionoplacinae Alcock, 1900; the pilumnid Rhizopinae Alcock, 1900; the Pseudorhombilidae Alcock, 1900; the Hexapodidae Miers, 1886; the Hymenosomatidae MacLeay, 1838; 
and the Pinnotheroidea De Haan, 1833. (The pinnotheroids are discussed in more detail below.) Coxal-sternal apertures have been viewed by some authors (Hendrickx, 1998; Türkay, 1983) to represent an evolutionary transition between the heterotrematous and thoracotrematous states, so implying that the coxal-sternal condition is a necessary precursor step to the acquisition of bonafide sternal apertures.

Coxal-sternal apertures appear upon superficial inspection to be sternal seminal duct openings. However, dissection reveals that the "penis" originates on the coxa of pereiopod 5 and passes along a sternal canal to emerge either through the wall of sternite 8, or near to the border of sternites 7-8 (Guinot, 1978; Guinot \& Bouchard, 1998). We conclude here that coxal-sternal apertures are simply an embellishment of the heterotreme groundpattern (Guinot, 1979), and that this arrangement involves no real modifications of the pathway of the seminal duct through endosternite 8 and of the coxa of pereiopod 5. Coxal-sternal apertures arise from two independent anatomical steps: (1) the development of a depression on the external surface of sternite 8 to accommodate the penis, and (2) the formation of a penial covering by either episternite 7 , sternite 8 , or both. It should be noted that within many of the (sub)families that possess coxal-sternal openings taxa can be found that represent one of each of the different stages of coxal-sternal aperture development, although each group usually includes some taxa with coxal apertures typical of heterotremes (e.g., Hendrickx, 1998).

The advanced stages of coxal-sternal aperture development seen in various euryplacines, prionoplacines, and pseudorhombilids would therefore appear to be group-specific characteristics rather than a state indicating a sister-group relationship with thoracotremes. Furthermore, unequivocal thoracotremes lack both a depression on sternite 8 and any hint of a vestigial penial furrow on the surface of the sternite, because the seminal duct simply passes through the sternite (fig. 3B). It can therefore be concluded that coxal-sternal apertures fall securely within the heterotreme groundpattern, and that sternal apertures are fundamentally decoupled from the coxal-sternal condition. The absence of character states intermediate to the heterotrematous and thoracotrematous conditions can now be explained as being largely due to a "forbidden morphology" that does not allow the truly intermediate condition to develop (see above).

Careful examination of a range of eubrachyurans reveals even more subtle arrangements of the position of the male sexual apertures. Some taxa have a male sexual aperture that is positioned right at the margin of the coxa of pereiopod 5 and very close to the articulating membrane and sternite 8 . Other taxa have a male sternal aperture that is positioned at the lateral margin of sternite 8 , adjacent to the articulating membrane and the coxa of pereiopod 5 (see figs. $3 \mathrm{~A}$ and $3 \mathrm{H}$ of Guinot, 
1978). For example, the penes of the gecarcinid Epigrapsus politus Heller, 1862 (a thoracotreme) abut and are partially attached to the pereiopod 5 coxae.

The question arises (see Von Sternberg et al., 1999) as to whether it is possible that crabs with a sternal aperture near the fifth pereiopod coxa, and those with the pereiopod coxal orifice near sternite 8 , actually represent the intermediate steps of one transformation series (morphocline) linking the Heterotremata and Thoracotremata. To address this question adequately it is helpful to use the models and ideas provided by Salthe (1993), Schram (1983), Thomson (1988), and Webster \& Goodwin (1996) concerning character state development in morphogenetic systems. Any morphogenetic system entails a number of stable terminal states. A stable terminal state (for example, the adult state) is usually recognized as comprising typical adult features, which are robustly attained despite variation in parameter conditions (e.g., genotypic variability, environmental perturbation, and changes in ontogenetic precursors). This means that adult anatomies (or characters derived from these) tend to fall into more-or-less discrete groupings or groundpatterns with varying degrees of generality (Rieppel, 1993, 1994). One can model the alternative character states or Baupläne available to a morphogenetic system as basins of attraction or bowls (see, respectively, Schram, 1983, and Thomson, 1988), each basin separated from the others by a rim representing inaccessible, intermediate morphologies. This model applies so well to various developmental systems that the reader is referred to comprehensive works to provide specific examples (e.g., Thomson, 1988). Placing the heterotreme-thoracotreme distinction into this framework allows one to model two basins of attraction for eubrachyuran seminal duct apertures (coxal versus sternal). Viewed from this perspective, sternal apertures adjacent to the pereiopod 5 coxae and, conversely, coxal apertures next to sternite 8 constitute those states which are located near the boundary separating the two morphological basins. And this view was indeed supported by dissection of Epigrapsus politus (National Museum of Natural History, Smithsonian Institution, USNM 46610), which revealed that the seminal ducts remain in endosternite 8, although the penial sheaths are attached to the pereiopod 5 coxae (unpublished results). However, as Thomson (1988) points out, taxa are invariably freely distributed throughout the basin as "variations-on-a-theme" and there is little or no evidence to support the assumption that sister taxa occupy adjacent domains within the bowl. That is, there appears to be no support for the construction of evolutionary trajectories within morphogenetic basins, because taxa (even closely related ones) independently access different domains of the morphospace (Webster \& Goodwin, 1996). Coxal apertures near sternite 8 and sternal openings next to the fifth coxae are, therefore, simply examples of variants within the two morphological sets, as Epigrapsus illustrates, and not examples of transitional morphologies. This model predicts a hierarchy of groundpatterns (Rieppel, 1994), 
and a high homoplasy rate within groundpatterns. And this is indeed what is seen when eubrachyuran genera are subjected to morphology-based parsimony studies (Von Sternberg \& Cumberlidge, submitted).

The morphological evidence supports the view that the heterotrematous and thoracotrematous conditions are indeed alternative states of the eubrachyuran ontogenetic system, and that two equivalent sets are formed when male sexual aperture position characters alone are considered.

\section{MALE SEXUAL OPENINGS IN THE HEXAPODIDAE MIERS, 1886}

Hexapodids form a distinct group in that the fifth pereiopods are absent, with the exception of one taxon where these appendages are vestigial. Sternite 8 is also considerably reduced in length in most hexapodids and covered by the carapace; the external portions of the vasa deferentia emerge through apertures near (or on) the eighth sternite (Gordon, 1971). Hexapodids were tentatively assigned to the Thoracotremata by Guinot $(1978,1979)$ who presented a drawing of the seminal duct trajectory in Hexapus sexpes (Fabricius, 1798) s.l. (cf. Guinot, 1979, fig. 32, p. 115). It is clear from Guinot's drawing that Hexapus s.l. is a thoracotreme and examination of a dissected specimen of $H$. sexpes (USNM 120729) corroborated her figure. However, the relationship between the endophragmal system and vas deferens of Hexapus is peculiar in that the latter does not enter endosternite 8 . The terminus of the seminal duct passes over the sella turcica and emerges through a very short channel formed by the median end of sternite 8 (this sternite is divided into two lateral pieces in Hexapus), and a longitudinal depression on sternite 7. In fact, the median end of sternite 8 takes the form of a knob which is interposed between the penis and the abdomen; the penis passes between the sternite 8 projection and the sternite 7 depression to contact the male pleopods. The substantial reduction of the length and internal area of endosternite 8 makes it physically impossible for the vasa deferentia to be accommodated.

Given the extreme reduction or absence of the last ambulatory limbs, coupled with the anomalous condition of the eighth sternite, the Hexapodidae raises some interesting problems for the heterotreme-thoracotreme distinction. It is clear that, since the fifth pereiopods are absent, the thoracotrematous condition could be an anatomical modification which accompanied the loss of these appendages and/or the reduction of sternite 8. According to such a view, hexapodids are morphologically thoracotremes although they are derived from heterotrematous precursors not shared by the other thoracotremes. Another possibility is that hexapodids arose from within the Thoracotremata with the reduction of the last thoracic sternite altering the topographical relationship of the seminal ducts. While 
the systematic position of the Hexapodidae is uncertain, there is independent evidence that allows us to ascertain which of the two hypotheses is most likely correct.

First, hexapodids have second through fourth pereiopods with meri which are distinctly triangular in cross-section, an apomorphy characteristic of all thoracotremes, pinnotheroids, and nontrichodactylid freshwater crabs (Von Sternberg et al., 1999). Diverse heterotreme groups such as goneplacids s.l., portunoids, and xanthoids possess ambulatory limb meri which are round or oval in cross-section. Second, the endostomial palate of hexapodids is not medially divided but instead consists of a complete plate; this too is an advanced feature exhibited only by thoracotremes and their allied groups (Von Sternberg et al., 1999). And the general habitus of the hexapodids suggests that they are related to the pinnotheroids, a group which is undoubtedly nested within the Thoracotremata (see below). All of the above, when considered along with the thoracotrematous condition, lends support for hexapodids being a thoracotreme clade, albeit a highly derived assemblage.

Guinot \& Richer de Forges (1997) removed the Hexapodidae from the Thoracotremata and placed this taxon in the Heterotremata. The justification for this transfer is stated to be based (at least in part) on Lago's (1988) study of hexapodid larval development (Guinot \& Bouchard, 1998). Lago (1988) noted a combination of plesiomorphic ("cyclometopous") and apomorphic ("catometopous") states appearing in the larval stages of Spiroplax spiralis (Barnard, 1950). Because larval goneplacids s.l. and pilumnids also have mosaic larval phenotypes, Lago (1988) suggested a close relationship between the polyphyletic Goneplacidae and the Hexapodidae. However, this author also stated that the larval characters exhibited by Spiroplax are more derived than those seen in goneplacids and xanthids and are equivalent to those of grapsoids. Given that the apomorphic larval states of Spiroplax align the hexapodids with thoracotremes, Lago's (1988) findings are actually congruent with the derived (adult) morphological states noted above.

\section{COMMENTS ON THE PINNOTHEROIDEA}

Guinot \& Richer de Forges (1997) transferred the pinnotheroids from the Thoracotremata to the Heterotremata as the apertures for the vasa deferentia are stated to be coxal, although emergent seminal ducts (penes) pass through sternal troughs (Guinot \& Bouchard, 1998). An examination of key anatomical features in basal pinnotheroid taxa supports placement of this group within the Thoracotremata (Von Sternberg, unpublished). It thus appears likely that some or all of the derived pinnotheroid lines have re-accessed the plesiomorphic 
condition. Assuming a monophyletic Pinnotheroidea, a cladistic pattern where the thoracotrematous condition is basal to the derived heterotrematous state would suggest an intraclade transition, although the direction of such a transition is opposite that assumed in the above-mentioned evolutionary scenarios.

\section{CLADISTIC CONSIDERATIONS}

When male sexual aperture position characters were included in a parsimony study together with a suite of other morphological characters (Von Sternberg \& Cumberlidge, 1999; Von Sternberg et al., 1999) a more detailed conclusion was reached. Those studies found support for the hypothesis of a paraphyletic Heterotremata and a monophyletic Thoracotremata which conflicts with the hypothesis of De Saint Laurent (1980) who placed the Heterotremata and Thoracotremata as sister groups within the Eubrachyura (fig. 1A). Further, the cladistic analyses of Von Sternberg \& Cumberlidge (1999) and Von Sternberg et al. (1999) strongly support the idea that a coxal male sexual aperture is a generalized anatomical state and that a sternal male sexual aperture is a specialized anatomical state. These works showed the Eubrachyura to be defined by the possession of coxal male sexual apertures, and the Thoracotremata to be defined by sternal male sexual apertures (see also Jamieson, 1994).

From a pattern cladistic standpoint (Rieppel, 1988, 1994) there are two main eubrachyuran types, but these are not equivalent because the thoracotrematous (autapomorphic) form is nested within the heterotrematous groundpattern (with a reversal in, or at the base of, the Pinnotheroidea). In the terminology of Schram (1983) and Thomson (1988) the thoracotreme morphogenetic basin is positioned within the heterotreme space (fig. 1B). The hypothesis that heterotrematous and thoracotrematous crabs represent parallel adaptive grades has no validation from this perspective (see also De Saint Laurent, 1980b), regardless of whether one subscribes to a typological (horizontal) or nested hierarchical (vertical) depiction of relationships within the Eubrachyura.

The issue of phylogenetic precedence (anagenetic succession) will now be addressed. It is reasonable to infer that coxal male sexual apertures are the phylogenetic Anlagen of sternal male sexual apertures (the apomorphic state), because coxal apertures are found in rather underived and putatively basal eubrachyurans. Further, it could be postulated that eubrachyurans must first have had heterotrematous ancestry in order for them to access the thoracotrematous condition. The cladistic studies of Von Sternberg \& Cumberlidge (1999) and Von Sternberg et al. (1999) add credence to such a view.

Cladograms of eubrachyuran taxa (Von Sternberg \& Cumberlidge, 1999; Von Sternberg et al., 1999) position coxal male sexual apertures at the node for 
all eubrachyurans and sternal male sexual apertures at a more distal location. This reflects the fact that a "primitive" eubrachyuran habitus is invariably associated with coxal apertures (Guinot, 1978, 1979). Yet the very nature of the heterotremethoracotreme distinction makes the concept of "phylogenetic precedence" untenable because one condition excludes the other. Simply put, there is neither ontogenetic nor anatomical evidence to support the hypothesis that coxal male sexual apertures have temporal precedence over sternal male sexual apertures (witness the pinnotheroids). The phylogenetic (or gradistic) idea that coxal apertures must have arisen prior to sternal ones only obtains if one is willing to conflate a nested hierarchical relationship with a temporal scheme (see Rieppel, 1988, 1993, 1994 for this logical fallacy). While many are willing to make this conflation (e.g., Hendrickx, 1998), such gradualistic speculations are ruled out by the observation that any transition between the heterotreme and thoracotreme groundpatterns necessarily entails a saltational change (i.e., surpassing the "rim" that separates domains of morphospace).

The association of sternal male sexual apertures with a number of other putatively advanced states has led some authors (e.g., Rice, 1983) to make conclusions that go beyond the available evidence. The existence of a number of highly derived ("catometopan") eubrachyurans that have coxal male sexual apertures (e.g., many "goneplacid" groups and pinnotheroids (Guinot \& Bouchard, 1998)) does not support the perceived association of sternal male sexual apertures with "advanced" eubrachyuran characters. Indeed, these latter groups were once placed in the Thoracotremata.

All true freshwater crabs (Potamoidea, Gecarcinucoidea, Pseudothelphusoidea, and Trichodactylidae) are heterotremes, and all non-trichodactylid crabs possess many other characters of the carapace, epistome, endostome, male abdomen, and pereiopods that would align them with the thoracotremes (Cumberlidge, 1999; Von Sternberg \& Cumberlidge, 1999; Von Sternberg et al., 1999). Indeed, in our opinion, most of the more than 850 species of Old World freshwater crabs and New World pseudothelphusids would be placed in the Thoracotremata and aligned with the gecarcinids, grapsoids, and ocypodoids s.l. were it not for their coxal male sexual apertures. In summary, it is clear that there exists a wide array of derived eubrachyurans that have coxal male sexual apertures.

It remains possible that an extremely rapid diversification of eubrachyurans could have led to the nearly simultaneous appearance of heterotrematous and thoracotrematous crabs. If this were so, the present character state distributions among families would merely have the appearance (in retrospect) that one group has led to the other (see Gordon, 1999). The resolution of this difficult problem requires comprehensive and detailed anatomical comparisons together with cladistic analyses that use a wide range of fossil and extant eubrachyurans. 
The morphological evidence (Von Sternberg \& Cumberlidge, 1999; Von Sternberg et al., 1999) points to the placement of the freshwater crabs (minus the Trichodactylidae H. Milne Edwards, 1853), and (possibly) pinnotheroids as putative sister groups of the Thoracotremata. While cladistic studies using an array of eubrachyuran genera (Von Sternberg \& Cumberlidge, submitted) place the pseudothelphusids and Old World freshwater crabs together as the sister clade of the thoracotremes, too few pinnotheroids have been studied to rule out a pinnotheroid-thoracotreme relationship. Nevertheless, it can be established that many aspects of the "catometopan facies": slender third maxilliped exopods, a median triangular epistomial projection, a complete endostome (lacking a median gutter), meri of pereiopod 1-5 that are triangular in outline, and so on; delimit a more inclusive grouping than that defined by sternal apertures alone. The Thoracotremata are also positioned within this more inclusive group.

Magalhães \& Türkay (1996) observed that sternal male sexual apertures have no "adaptational" association with typical catometopan features such as a broad sternum, an inflated and rounded carapace, and/or terrestrial habits. This weakens the idea that sternal male sexual openings arose as a consequence of selection pressures for increased mobility of the fifth pereiopods or a particular facies.

\section{CONCLUSION}

In conclusion, three things need to reiterated. First, the Eubrachyura comprise two discrete morphological types, distinguished on the basis of two mutually exclusive character states (coxal male sexual apertures and sternal male sexual apertures, respectively). Neither one of these two morphological conditions appears to be the ontogenetic, anatomical, or phylogenetic precursor of the other. There is no support for the position that "coxal-sternal" apertures, or coxal openings near sternite 8 , or sternal openings adjacent to the lateral margin represent evolutionarily intermediate stages. Sets of character states such as these represent variants of a particular groundpattern.

Second, the distribution of sternal male sexual orifices and coxal male sexual apertures among eubrachyurans is largely independent of the ecology of the animals and of the morphology of their carapace, sternum, or ambulatory legs. Just as there are large numbers of estuarine, freshwater, and (semi)terrestrial thoracotremes, so are there hundreds of freshwater and (semi)terrestrial heterotremes. And third, the Heterotremata is a paraphyletic group although the term "heterotreme" is useful for denoting those taxa within the Eubrachyura which possess the more general condition of coxal male sexual apertures. The latter statement reflects the results of recent parsimony analyses although it still needs to be confirmed by a more expansive database. 


\section{ACKNOWLEDGEMENTS}

The research of the senior author was funded by a Smithsonian Postdoctoral Fellowship. We thank Dr. Nancy Voss, Curator of the Marine Invertebrate Museum, Rosenstiel School of Marine and Atmospheric Science (Miami, Florida), for granting the first author ample work space and free access to specimens during his recent (January 5-12, 2000) visit to the museum. Doctor Rafael Lemaitre (Smithsonian Institution) is also thanked for carefully reviewing an earlier draft of the manuscript. In addition, Dr. Danièle Guinot is warmly thanked for her always enlightening comments concerning the heterotreme-thoracotreme distinction.

\section{REFERENCES}

Cochran, D. M., 1935. The skeletal musculature of the blue crab, Callinectes sapidus Rathbun. Smithson. misc. Coll., 92 (9): 1-76.

Cumberlidge, N., 1999. The freshwater crabs of West Africa, family Potamonautidae. Faune et Flore Tropicales, 35: 1-382. (IRD, Paris).

Gordon, I., 1971. On the thoracic sternum in the subfamily Hexapodinae (Brachyura, Goneplacidae). Crustaceana, 21: 106-110.

Gordon, M. S., 1999. The concept of monophyly: a speculative essay. Biol. Phil., 14: 331-348.

Gould, S. J. \& R. C. Lewontin, 1979. The spandrels of San Marco and the panglossian paradigm: a critique of the adaptationist programme. Proc. Royal Soc., London, (B) 205: 581598.

Guinot, D., 1978. Principes d'une classification évolutive des Crustacés Décapodes Brachyoures. Bull. biol. France Belgique, (n.s.) 112 (3): 211-292.

— —, 1979. Données nouvelles sur la morphologie, la phylogenèse et la taxonomie des Crustacés Décapodes Brachyoures. Mém. Mus. natn. Hist. nat., Paris, (A, Zool.) 112: 1-354, pls. 1-27.

GuINOT, D. \& J.-M. BOUCHARD, 1998. Evolution of the abdominal holding systems of brachyuran crabs (Crustacea, Decapoda, Brachyura). Zoosystema, 20 (4): 613-694.

Guinot, D. \& B. Richer DE Forges, 1997. Affinités entre les Hymenosomatidae MacLeay, 1838 et les Inachoididae Dana, 1851 (Crustacea Decapoda Brachyura). Zoosystema, 19 (2-3): 453-502.

Hartnoll, R. G., 1968. Morphology of the genital ducts in female crabs. Journal Linnean. Soc. London, (Zool.) 47: 279-300.

HENDRICKX, M. E., 1998. A new genus and species of "goneplacid-like" brachyuran crab (Crustacea: Decapoda) from the Gulf of California, Mexico, and a proposal for the use of the family Pseudorhombilidae Alcock, 1900. Proc. biol. Soc. Washington, 111 (3): 634-644.

Jamieson, B. G. M., 1994. Phylogeny of the Brachyura with particular reference to the Podotremata: evidence from a review of spermatozoal ultrastructure (Crustacea, Decapoda). Phil. Trans. Royal Soc. London, (B) 345: 373-393.

LAGO, R. F., 1988. Larval development of Spiroplax spiralis (Barnard, 1950) (Brachyura: Hexapodidae) in the laboratory; the systematic position of the family on the basis of larval morphology. Journ. Crust. Biol., 8 (4): 576-593.

Magalhães, C. \& M. TÜRKAY, 1996. Taxonomy of the Neotropical freshwater crab family Trichodactylidae. I. The generic system with description of some new genera (Crustacea: Decapoda: Brachyura). Senckenbergiana biol., 75: 63-95.

RiCE, A. L., 1983. Zoeal evidence for brachyuran phylogeny. Crust. Issues, 1: 313-329. 
RiEPPEL, O., 1988. Fundamentals of comparative biology: 1-202. (Birkhäuser, Basel and Boston). — —, 1990. Structuralism, functionalism, and the four Aristotelian causes. Journ. Hist. Biol., 23: 291-320.

- —, 1993. The conceptual relationship of ontogeny, phylogeny, and classification: the taxic approach. Evol. Biol., 27: 1-32.

— - 1994. Homology, topology, and typology: the history of modern debates. In: B. K. HALL (ed.), Homology: the hierarchical basis of comparative biology: 63-100. (Academic Press, New York).

Saint Laurent, M. DE, 1980a. Sur la classification et la phylogénie des Crustacés Décapodes Brachyoures. I. Podotremata Guinot, 1977, et Eubrachyura sect. nov. C. R. hebd. Séances Acad. Sci. Paris, (D) 290: 1265-1268.

— —, 1980b. Sur la classification et la phylogénie des Crustacés Décapodes Brachyoures. II. Heterotremata et Thoracotremata Guinot, 1977. C. R. hebd. Séances Acad. Sci. Paris, (D) 290: 1317-1320.

Salthe, S. N., 1993. Development and evolution: complexity and change in biology: i-xiv, 1-357. (MIT Press, Cambridge, MA).

SCHRAM, F. R., 1983. Method and madness in phylogeny. Crust. Issues, 1: 331-350.

SECRETAN, S., 1998. The sella turcica of crabs and the endophragmal system of decapods. Journal nat. Hist., London, 32: 1753-1767.

Spears, T., L. G. Abele \& W. Kim, 1992. The monophyly of the brachyuran crabs: a phylogenetic study based on 18S rRNA. Journ. Crust. Biol., 41 (4): 446-461.

Sternberg, R. von \& N. Cumberlidge, 1999. A cladistic analysis of the genus Platythelphusa A. Milne-Edwards, 1887 from Lake Tanganyika, East Africa (Decapoda: Potamoidea: Platythelphusidae) with comments on the phylogenetic position of the group. Journ. nat. Hist., London, 33: 493-511.

- — \& - - in press. Notes on the position of the true freshwater crabs within the brachyrhynchan Eubrachyura (Crustacea: Decapoda: Brachyura). Hydrobiologia.

SternberG, R. vON, N. CUMBERLIDGE \& G. RodRIGUEZ, 1999. On the marine sister groups of the freshwater crabs (Crustacea: Decapoda). Journ. zool. Syst. evol. Res., 37: 19-38.

Thomson, K. S., 1988. Morphogenesis and evolution: i-vi, 1-154. (Oxford University Press, New York).

TÜRKAY, M., 1983. The systematic position of an Australian mangrove crab Heloecius cordiformis (Crustacea: Decapoda: Brachyura). Mem. Australian Mus., 18: 107-111.

WEBSTER, G. \& B. GOODWIN, 1996. Form and transformation: generative and relational principles in biology: i-xiv, 1-287. (Cambridge University Press, Cambridge).

First received 25 April 2000.

Final version accepted 19 September 2000. 